\title{
Minimizing greenhouse gas emissions of an industrial wastewater treatment plant in terms of water-energy nexus
}

\author{
Pelin Yapıcıoğlư ${ }^{1}$ Özlem Demir ${ }^{1}$
}

Received: 7 May 2021 / Accepted: 23 August 2021 / Published online: 5 November 2021

(C) The Author(s) 2021

\begin{abstract}
In this paper, $\left(\mathrm{CO}_{2}\right)$ and methane $\left(\mathrm{CH}_{4}\right)$ emissions of an industrial wastewater treatment plant were monitored. GHG emissions originated from treatment processes were considered as the direct emissions and determined using closed chamber method. GHG emission due to energy consumption was regarded as the indirect emissions. In the second stage of the study, it was aimed to reduce GHG emissions in terms of water-energy nexus. If the plant is operated under design conditions, energy consumption would be lower according to water-energy nexus. Also, the effect of design conditions on GHG emissions was investigated. Firstly, the correlation was defined between GHG emissions and operational parameters in terms of chemical oxygen demand (COD) and wastewater flow rate using Monte Carlo simulation. Then, design COD and wastewater flow rate were simulated to determine the possible GHG emission for each month. The simulation results show that minimization of GHG emissions might be possible if wastewater plant is operated under design conditions. The minimum greenhouse gas emission in the result of the simulation study is $8.25 \mathrm{~kg} \mathrm{CO}_{2}$-eq/d if the plant is operated under design COD and flow rate. Total reduction in GHG emissions is approximately $30 \%$ if the plant is operated under design conditions.
\end{abstract}

Keywords Industrial wastewater treatment · Greenhouse gas emissions · Reduction · Design conditions · Water-energy nexus

\section{Introduction}

Greenhouse gas (GHG) emissions from wastewater treatment plants have become a current focus and are considered as one of the main environmental challenges, in the last decade. According to Intergovernmental Panel on Climate Change (IPCC) Directive, GHG emissions are mainly resulted from anthropogenic activities (IPCC 2014). Wastewater treatment plants (WWTPs) are one of these anthropogenic resources (Kumar et al. 2021). The main greenhouse gas generation points of WWTPs are treatment processes, energy consumption, chemical use, sludge stabilization processes, planned maintenance operations and transportation in the plant (IPCC 2014). The major emissions resources of WWTPs are energy consumption and biological, chemical and biochemical treatment processes to obtain effluent

Özlem Demir

odemir@harran.edu.tr

1 Engineering Faculty, Department of Environmental Engineering, Harran University, Osmanbey Campus, Şanlıurfa, Turkey quality. Especially, electricity consumption mainly generates GHG emissions in the WWTPs. Greenhouse gas emissions could be grouped under two main headings as the direct and indirect emissions (Parravicini et al. 2016). The direct GHG emissions for wastewater treatment plants mean to the emissions generated in the sewage collection and discharging points. The other direct emission resource is wastewater treatment units. The indirect GHG emissions are caused by electricity consumption, chemical use and transfer, sludge handling and stabilization processes. Total greenhouse gas emission is the sum of these emissions (Masuda et al. 2015; Parravicini et al. 2016). In this study, the emissions due to wastewater treatment processes are considered as the direct emissions. Indirect emissions of the plant are the emissions resulted from electricity consumption. Indirect GHG emissions are originated from water-energy nexus. The water-energy nexus evaluation tool is a kind of systematic approach that underlines the relationship between water and energy (Landa-Cansigno et al. 2020; Yapıcıŏglu and Yeşilnacar 2020). It is clear that energy is a need for water treatment and distribution. Besides, energy is not only directly utilized for water production, distribution and 
treatment, but also is depleted for cooling, pumping and heating. However, several researchers disregard wastewater treatment technologies as insignificant for the water-energy nexus, focused on more on water consumption in the energy sector. Freshwater bodies are regarded as important sources of greenhouse gas to the atmosphere (Kumar et al. 2019a). Also, water, wastewater treatment and distribution processes emit GHG emissions considering water-energy nexus. In fact, energy consumption of the WWTPs should be a crucial consideration of the water-energy nexus. The energy consumption of a wastewater treatment plant is identified by both operational and design parameters containing the technique carried out in the treatment process, the size of the plant, effluent water standards, influent wastewater characterization, the volume of wastewater treated and the pollutant load of the inlet wastewater (Castellet-Viciano et al. 2018, Metcalf and Eddy 2014). Among them, energy need of a plant majorly depends on operational parameters that are the volume of wastewater treated (flow rate) and organic load (biological oxygen demand (BOD), chemical oxygen demand (COD), total suspended solid (TSS), fats, oil and grease (FOG), etc.) (Metcalf and Eddy 2014; Yapıcıoğlu and Yeşilnacar 2020). In order to reduce greenhouse gas emissions, energy consumption should be limited considering these parameters. It is considered that energy consumption would be lower if the plant is operated under design conditions (Castellet-Viciano et al. 2018). From this point of view, this paper aimed to reduce GHG emissions which contain carbon dioxide $\mathrm{CO}_{2}$ and methane $\mathrm{CH}_{4}$ emissions in terms of water-energy nexus considering design and operational parameters.

$\mathrm{CO}_{2}$ and $\mathrm{CH}_{4}$ have been considered as the main greenhouse gases of WWTPs (IPCC 2014; Kumar et al. 2021, 2019a). $\mathrm{CH}_{4}$ has been released directly in every units of wastewater treatment plant and should be assessed. IPCC assumes that $\mathrm{CH}_{4}$ is generated at the anaerobic conditions (IPCC 2014). $\mathrm{CH}_{4}$ is generated in the result of anaerobic digestion of organic materials. According to IPCC Directive, $\mathrm{CH}_{4}$ especially releases from grit chambers and aeration tanks at WWTPs (IPCC 2014). Aeration tanks are regarded as the main $\mathrm{CH}_{4}$ resources due to biochemical treatment process and the possibility of anaerobic conditions in the result of inadequate aeration. Meanwhile, the presence of methanogens in waste sludge shows that methane is produced in a wastewater treatment plant. $\mathrm{CO}_{2}$ has been released in the result of biodegradation of organic materials such as microbial respiration of the microorganisms. If any living organism is present at the treatment area, $\mathrm{CO}_{2}$ is emitted from WWTPs. These emissions are generated in the result of treatment processes and energy consumption in the WWTPs.

There are several studies in the literature related to this topic. In recent years, various modeling, design and operational tools have been defined at global scale to make strategic policies to minimize GHG emissions (Kumar et al. 2021). Many approaches contain greenhouse gas modeling, empirical models based on emission factors (IPCC, 2014; Kumar et al. 2021), elementary and comparative models depending on the process and dynamic and steady-state models (Guo and Vanrolleghem 2014; Mannina et al. 2016; Pata and Kumar 2021; Kumar et al. 2019b). Mathematical modeling of GHG emissions is based on two main approaches. These approaches are the dynamic comparative models and steady-state process models (Mannina et al. 2016). These models include emission factors, plant characterization such as influent and effluent values, wastewater flow, allowable discharging standards. The numerical methods are supported by a software or GHGs emissions monitoring. The other method for GHG estimation is gas monitoring and using simple equilibrium model with monitoring gas concentrations. Also, experimental studies have been carried out using gas chromatography and micro-gas sensors. Masuda et al. (2015) observed the seasonal variation of greenhouse gas emissions in a wastewater treatment plant using gas sampling and monitoring method (Masuda et al. 2015). The other study based on GHG monitoring was carried out by Rodriguez-Caballero et al. (2014). Using commercial software is a widespread method to determine the GHG emissions. The main commercial software supported with GHG modeling is Gams, Steady, West and Biowin, Monte Carlo simulation and DEA models. MolinosSenantea et al. (2014) have studied on environmental and economical performances of WWTPs and possible minimization of GHG emissions (Molinos-Senante et al. 2014). Kyung et al. (2015) have developed a model for the determination of the GHG emissions from WWTPs. They estimated the possible variation of GHG emissions from the WWTPs (Kyung et al. 2015).

The studies in the literature show that the amount and distribution of the greenhouse gases produced depend on the input wastewater characteristics, leaving water standards, wastewater and sludge treatment processes used and operating conditions. Accordingly, it is necessary to pay close attention to plant design and operation to minimize greenhouse gas production. In this study, a new model was developed depending on $\mathrm{CO}_{2}$ and $\mathrm{CH}_{4}$ emissions monitoring. The emission monitoring chamber was designed by the authors, and GHG estimation tool was developed based on this monitoring chamber. This study aimed to develop an actual and extensive methodology for the determination of GHG emissions from WWTPs. In the second stage of the study, it was aimed to decrease the GHG emissions in terms of water-energy nexus considering the operational and design parameters. From this point of view, the effects of design and operational conditions on GHG emissions were examined using Monte Carlo simulation. The novelty of this study is that a new GHG emission estimation tool was developed 
based on designed emission isolation flux chamber. The other originality of this paper is that Monte Carlo Simulation was carried out to minimize the GHG emissions considering design and operational parameters. Various mitigations and control strategies such as process modifications, innovative technologies (microalgal treatment, CANDO process, etc.) energy control policies focusing on operational strategies for wastewater treatment plants associated GHG emissions have been recommended by several researchers (Kumar et al. 2021). This study has differed from the previous studies that the operational conditions were corresponded with the GHG emissions. GHG emissions values related to design conditions were estimated according to this correspondence using Monte Carlo simulation in terms of water-energy nexus.

\section{Materials and methods}

\section{Description of the study area}

An organized industrial zone central wastewater plant was selected as a pilot plant in the province of Sanliurfa. Figure 1 shows the study area. The reason of selecting this plant is that its location is within the provincial boundaries and the convenience of transportation. Also, this plant has high industrial pollution load. The plant which is established in a closed area of $10.000 \mathrm{~m}^{2}$ is operated continuously and has a wastewater treatment capacity of $6000 \mathrm{~m}^{3} / \mathrm{d}$.

Coagulation and flocculation processes and activated sludge process are carried out together in this plant. The plant is a biochemical wastewater treatment plant. In the coarse and fine screens, the solids are retained. In the equalization tank, the wastewater flow is balanced. The points where the processes take place are aerated grit chamber (inorganic matters, total suspended solids (TSS) and partial chemical oxygen demand (COD) removal), primary settling tank (TSS and partial COD removal), coagulation and flocculation tanks (fats, oil and grease (FOG), TSS and COD removal), aeration tanks (organic matters, TSS and COD removal) and the secondary settling tank (TSS and COD removal). Figure 2 demonstrated the treatment process flow scheme.

\section{Greenhouse gas emissions monitoring}

In this paper, $\mathrm{CO}_{2}$ and $\mathrm{CH}_{4}$ emissions were observed using a new developed monitoring method. It is a type of closed chamber (CC) method. The closed chamber method in

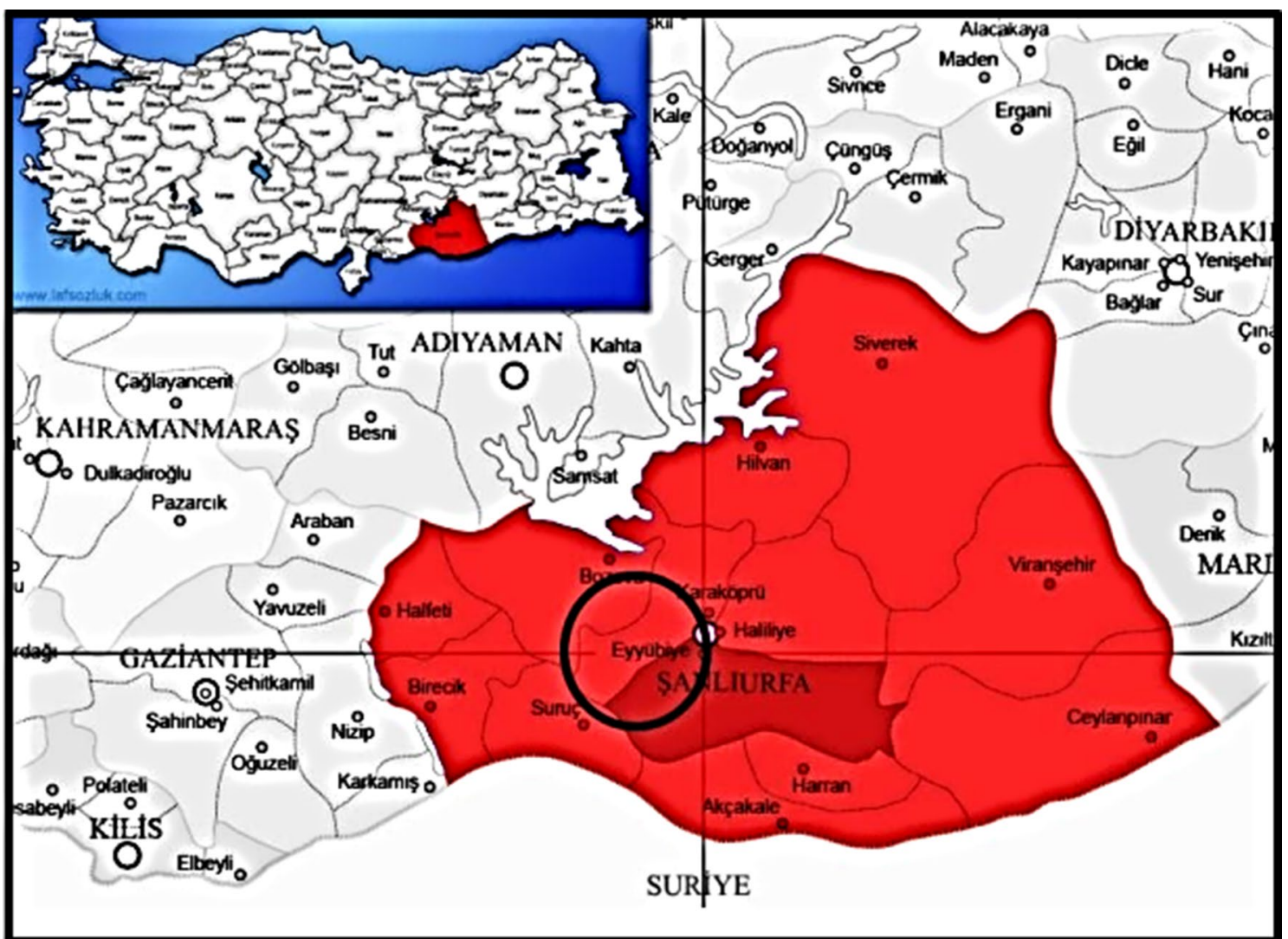

Fig1 The map of study area 


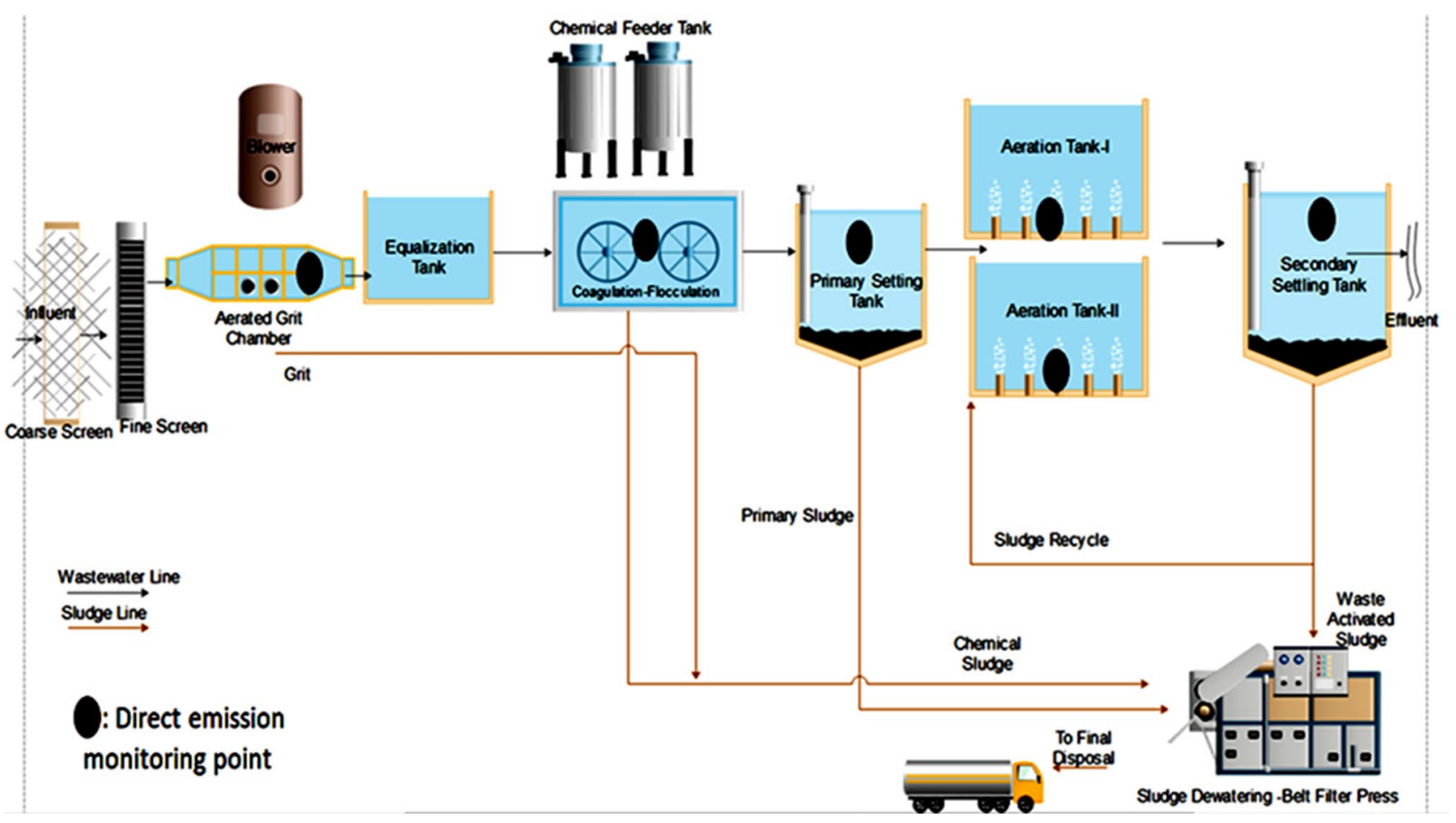

Fig2 Wastewater treatment process flow scheme and GHG emissions monitoring point

this study contains an emission isolation flux chamber and Drager X-Am 5000 gas analyzer. The gas analyzer is put in a pump slot, and the gas sampling is carried out. The gas has been retained in the emission isolation flux chamber for a quite duration. The emission isolation flux chamber was designed by the authors. The emission isolation flux chamber whose material is galvanized sheet chamber is the gas collector as the closed chamber method. It is in a spherical form and is put on the floating hauler equipment on the wastewater. The sub-section of the emission isolation flux chamber is surfaced with a filter. The emission isolation flux chamber is $31 \mathrm{~cm}$ in diameter and height. The total volume of the emission chamber is $1.56 \times 10^{-2} \mathrm{~m}^{3}$. The gas was retained in $25 \mathrm{~min}, 30 \mathrm{~min}$, $45 \mathrm{~min}$ and $60 \mathrm{~min}$, and the ratios of gas were monitored. The optimum gas retention time is $30 \mathrm{~min}(0.5 \mathrm{~h})$ due to the fact that monitored gas amounts were fixed in the end of $30 \mathrm{~min}$ of duration. The GHG flow could be regarded as the volume of the flux chamber. It was assumed that $1.56 \times 10^{-2} \mathrm{~m}^{3}$ of gas as the volume of emission isolation flux chamber is retained for $0.5 \mathrm{~h}$ on the open-top treatment units. So, the GHGs flow is $3.12 \times 10^{-2} \mathrm{~m}^{3} / \mathrm{h}$. This corresponds to nearly $30 \mathrm{~kg} / \mathrm{h}$ of gas flow (According to the volume-weight conversions, $1 \mathrm{~kg}$ corresponds to $0.001041 \mathrm{~m}^{3}$ ). The calculation of this value is based on the volume of the flux chamber and the retention time. $\mathrm{CO}_{2}$ and $\mathrm{CH}_{4}$ emission were figured out by observing the gas percentage ratios (\%). $\mathrm{CO}_{2}$ and $\mathrm{CH}_{4}$ emissions monitoring have been performed 12 times per a year.

Figure 2 demonstrates the direct GHG emissions monitoring points in this industrial WWTP. Figure 3 shows the methodology of the study is given in line-diagram. Greenhouse gas monitoring points are aerated grit chamber, primary settling tank, aeration tanks, coagulation and flocculation tank and secondary settling tank where biochemical and physicochemical reactions form. GHG emissions have been monitored in these units because the closed chamber method could be used for the open-top units.

\section{Determination of direct greenhouse gas emissions}

A basic mathematical model was developed to figure out the GHG emissions in the wastewater treatment units where the closed chamber method was carried out. A new estimation tool was developed, in this paper (Eq. 1). Based on kinetic theory, the volume of gas collected within the emission flux chamber is the volume of the emission flux chamber as the total gas volume $\left(\mathrm{CH}_{4}, \mathrm{CO}_{2}, \mathrm{~N}_{2} \mathrm{O}, \mathrm{H}_{2} \mathrm{~S}\right.$, etc.). From this point of view, $1.56 \times 10^{-2} \mathrm{~m}^{3}$ of gas was captured for $30 \mathrm{~min}$ as the optimum retention time. The gas flow is nearly $30 \mathrm{~kg}$ per hour. It was also assumed that gases did not react with each other. The gas amount was figured out by monitoring the ratios of $\mathrm{CO}_{2}$ and $\mathrm{CH}_{4}$ gases in the total gas volume on the Drager X-Am 5000 model gas analyzer. The greenhouse gas content in $\mathrm{kg}$ 
Fig. 3 Methodology used in the study

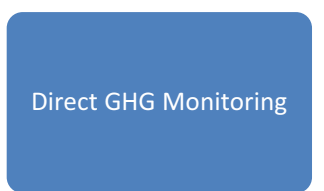

$\Rightarrow$
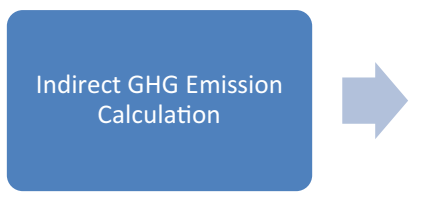

Minimization of GHG

emissions using Monte

Carlo Simulation
$\mathrm{CO}_{2-}$ eq/d was figured out by multiplying with global warming potentials (GWP) of $\mathrm{CO}_{2}$ and $\mathrm{CH}_{4}$. GWP values of $\mathrm{CO}_{2}$ and $\mathrm{CH}_{4}$ are 1 and 28, respectively (IPCC 2014).

$\mathrm{GHG}_{\text {direct }}=\left(F_{\mathrm{GHG}} \times R_{\mathrm{CH} 4, \mathrm{CO} 2}\right) / 100 \times \mathrm{GWP}_{\mathrm{CH} 4, \mathrm{CO} 2}$

where $\mathrm{GHG}_{\text {direct }}$ : Direct GHG Emission $\left(\mathrm{kg} \mathrm{CO}_{2}\right.$-eq/d), $\mathrm{F}_{\mathrm{GHG}}$ : The flow of GHG emission $(\mathrm{kg} / \mathrm{h}), \mathrm{R}_{\mathrm{CH} 4, \mathrm{CO}_{2}}$ : The ratios of $\mathrm{CH}_{4}$ or $\mathrm{CO}_{2}(\%), \mathrm{GWP}{ }_{\mathrm{CH} 4, \mathrm{CO} 2}$ : Global Warming Potential of $\mathrm{CO}_{2}$ or $\mathrm{CH}_{4}$.

\section{Determination of indirect greenhouse gas emissions}

The indirect emission is the greenhouse gas emission resulting from electricity consumption, in this study in terms of water-energy nexus. The wastewater sludge is not stabilized in this plant which will be disposed by the municipality, so sludge treatment is negligible, in this study. Only, electricity consumption was considered as the indirect emission.

Indirect GHG emission could be figured out using electricity consumption and emission factor related to regional emission factor of the country. Regional emission factor (Ef) was assumed as $0.497 \mathrm{~kg} \mathrm{CO}_{2} / \mathrm{kWh}$ in 2017 (International Energy Agency (IEA) 2016). The amount of the electricity consumption in the plant has been obtained from the electricity bills. The indirect $\mathrm{CO}_{2}$ emission is figured out by means of the equation given below (Eq. 2) (Kyung et al. 2015).

$\mathrm{GHG}_{\text {indirect }}=\mathrm{EC} \times \mathrm{Ef}$

where $\mathrm{GHG}_{\text {indirect }}$ : Indirect emission $\left(\mathrm{kg} \mathrm{CO}_{2}\right.$-eq/d), EC: Electricity consumption of the plant (kWh), Ef: Emission factor of Turkey $\left(\mathrm{kg} \mathrm{CO}_{2} / \mathrm{kWh}\right)$.

\section{Estimation of total GHG emissions}

Total greenhouse gas $\left(\mathrm{GHG}_{\text {total }}\right)$ emission is considered as sum of the direct and indirect emissions, in the WWTP. The calculation of total GHG emission is given in Eq. 3.
$\mathrm{GHG}_{\text {total }}=\mathrm{GHG}_{\text {direct }}+\mathrm{GHG}_{\text {indirect }}$

\section{Minimization of GHG emissions using Monte Carlo simulation}

Several methods have been applied for GHG emissions minimization from wastewater treatment plants. Innovative treatment technologies could be carried out to decrease the greenhouse gas emissions. Microalgal technology is known as one of the oldest GHG emissions minimization processes. $\mathrm{CO}_{2}$ assimilation is carried out due to the photosynthesis of microalgae in these systems (Maity et al. 2014). In recent years, biochar application is one of the GHG emission reduction technologies due to $\mathrm{CO}_{2}$ and $\mathrm{N}_{2} \mathrm{O}$ adsorption capacity (Qambrani et al. 2017). Modification of operating conditions and wastewater characterization is another GHG emission reduction technique (Yapıcıoğlu and Demir 2017). The final stage of the study comprised of the reduction in monitoring GHG emissions due to the treatment process using closed chamber method with the help of Monte Carlo simulation in terms of water-energy nexus. It is considered that energy consumption could be lower if the WWTPs operate under design conditions. So, the possible GHG emission was estimated related to design conditions using GHG emissions corresponded to operational parameters. For the possible reduction in GHG emissions, the effects of design and operational conditions on GHG emissions were examined using Monte Carlo simulation.

Monte Carlo assays have been performed depending on computational algorithms that rely on repeated random sampling to achieve numerical results. This method is often carried out in physical and mathematical problem. Monte Carlo technique is mostly applied for problem categories which are optimization, numerical integration, and generating draws from a probability distribution (Kroese et al. 2014). Monte Carlo Simulation is a 
numerical technique that produces random variables for modeling the risk or uncertainty of a system or optimizing the variables. Monte Carlo Simulation uses the probability distribution for modeling a random variable. Monte Carlo Simulation was performed for only direct emissions resulting from wastewater treatment processes. This consideration is based on that operational parameters lead to the greenhouse gas emissions resulting from the treatment process. @RISK software was used to perform the simulation. 5000 iterations and 1 simulation were performed for this study. Lognormal distribution was selected as the probability distribution.

Firstly, the correlation between operational condition which were influent flow rate and COD and direct GHG emission related to each month were defined using 5000 iterations and 1 simulation on a monthly basis. The model is given in Eq. 4. As uncertain inputs, operational COD $(\mathrm{mg} / \mathrm{L})$ and operating flow rate $\left(\mathrm{m}^{3} / \mathrm{d}\right)$ were entered. As outputs, the total direct GHG emissions from the process were considered.

$C=\operatorname{RiskOutput}($ Lognormal $)+\operatorname{RiskLognorm}\left(\mathrm{O}_{1} ; \mathrm{O}_{2}\right)$

$C=$ Correlation related to operational COD and flowrate, $\mathrm{O}_{1}=$ Operational COD and Flow rate values, $\mathrm{O}_{2}=$ Direct greenhouse gas emission values $\left(\mathrm{kg} \mathrm{CO}_{2}\right.$-eq/d).

After defining correlation, 5000 iterations and 1 simulation were performed to estimate the GHG emission related to design COD and flow rate using defined correlation. Design COD and flow rate were $10000 \mathrm{mg} / \mathrm{L}$ and $6000 \mathrm{~m}^{3} / \mathrm{d}$, respectively, for all months. In the result of lognormal distribution, GHG emission values related to design conditions for each month were generated. The model for the simulation of GHG emission is given in Eq. 5. Then, the reduction in GHG emission was calculated. COD was analyzed using standard methods (APHA 2005). Wastewater flow is measured with an automatic flow meter.

$G=\operatorname{RiskOutput}($ Lognormal $)+\operatorname{RiskLognorm}\left(D_{;} C\right)$

$G=\mathrm{GHG}$ emission related to design conditions $(\mathrm{kg}$ $\mathrm{CO}_{2}$-eq/d), $D=$ Design COD and Flow rate values, $C=$ Direct greenhouse gas emission values.

\section{Results and discussion}

The monitoring results of GHG emissions as direct, indirect and total were given in following sections. In the final stage, the minimization results of GHG emissions after Monte Carlo Simulation were shown.

\section{Direct GHG emissions}

The direct greenhouse gas emissions are sum of $\mathrm{CO}_{2}$ and $\mathrm{CH}_{4}$ emissions observed in the aerated grit chamber, primary settling tank, aeration tanks, coagulation and flocculation tank and secondary sedimentation tank. Total direct, $\mathrm{CO}_{2}$ and $\mathrm{CH}_{4}$ emissions in this industrial WWTP are given in Tables (1, 2 and 3).

Monthly variations of the direct GHG emission on process basis are shown in Figs. 4 and 5. Coagulation-flocculation tank was the main treatment unit which large amounts of direct GHG emissions were released. It could be considered that major physiochemical processes were carried out at coagulation-flocculation tank. Aeration tanks and aerated girt chamber were the other GHG emissions resources. No GHG emissions were monitored at primary and secondary settling tanks. In summer, GHG emissions were in the highest values. It could be resulted from climatic conditions and evaporation. In winter, the lowest GHG emissions were observed in this plant. It could be considered that seasonal variations have a strong effect on GHG emissions originated from treatment processes (Tables 4 and 5).

The results showed that the highest direct GHG emissions were observed in August (977.76 $\mathrm{kg} \mathrm{CO}_{2}$-eq/d). The lowest direct greenhouse gas emission was observed in January $\left(12.456 \mathrm{~kg} \mathrm{CO}_{2}\right.$-eq/d). As the temperature increases, there could be an increase in the greenhouse gas emission resulting from the process. $\mathrm{CH}_{4}$ emissions were observed in May, June, July and August. The highest $\mathrm{CH}_{4}$ emission was measured in August. It could be said that increasing temperature triggered $\mathrm{CH}_{4}$ formation in the treatment units. Aerated grit chamber and coagulation-flocculation tank were the resources of $\mathrm{CH}_{4}$ emissions. It could be said that $\mathrm{CH}_{4}$ was released in the summer due to anaerobic stratification in the coagulation-flocculation tank. At aerated grit chamber, it could be concluded that $\mathrm{CH}_{4}$ emission was emitted due to anaerobic conditions in compartments that were not adequately aerated.

Aeration tanks were the main resources of $\mathrm{CO}_{2}$ emissions. Here, it could be said that $\mathrm{CO}_{2}$ emission was released due to the respiration of the living microbial mass. The highest $\mathrm{CO}_{2}$ emission was measured with the value of $32.4 \mathrm{~kg} \mathrm{CO}_{2}$-eq/d in May. Another resource of $\mathrm{CO}_{2}$ emission was aerated grit chamber. From this monitoring result, $\mathrm{CO}_{2}$ emission could be released due to cell breathing as a result of microbial mass reproduction at aerated grit chamber. The vital activities of the microbial mass growth could be shown as the reason for the formation of $\mathrm{CO}_{2}$ emission at the aerated grit chamber.

Considering the process conditions, the highest $\mathrm{CH}_{4}$ emission was monitored at the lowest $\mathrm{COD}$ and flow rate. If the results were compared with the previous studies, similar findings could be obtained. Masuda et al. (2015) reported 

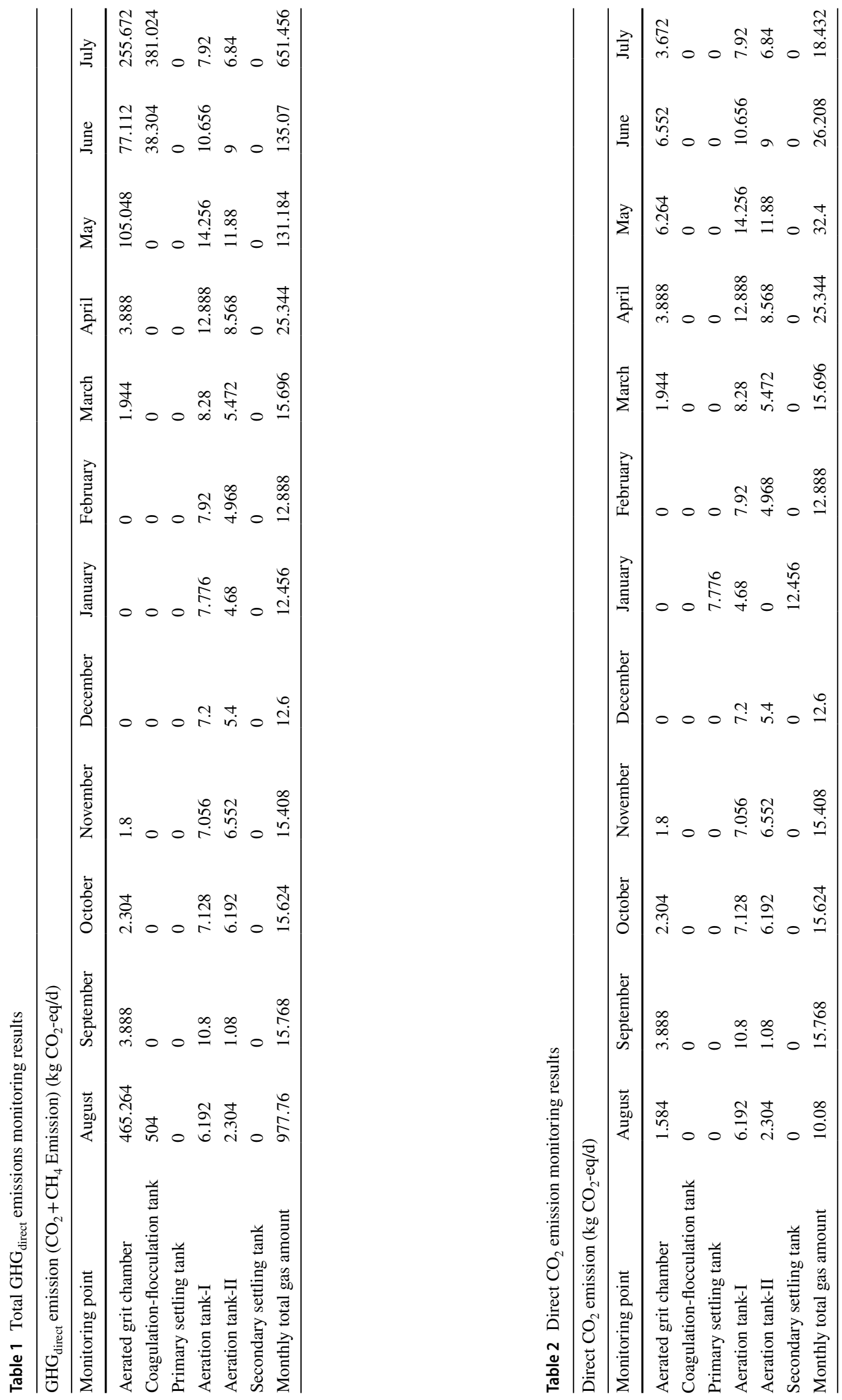


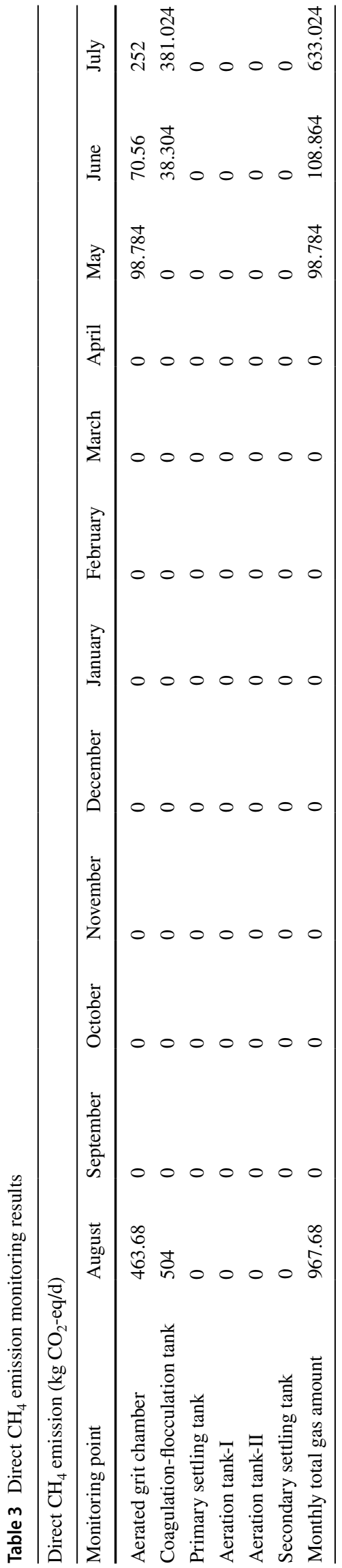

similarly with this study that the highest GHG emission was in summer and the lowest was in winter (Masuda et al. 2015). They observed the highest $\mathrm{CH}_{4}$ emission at the aeration tank; on the contrary, it was observed in the coagulation-flocculation tank in this study. Rodriguez-Caballero et al. (2014) monitored GHG emissions for aerated and non-aerated areas for an urban wastewater treatment plant during July and October (Rodriguez- Caballero et al. 2014). It was observed that the highest emission monitored at the aeration tank. They similarly monitored the lowest GHG emissions in winter. Kyung et al. (2015) monitored the GHG emissions in a wastewater treatment plant where 5-staged Bardenpho process was carried out (Kyung et al. 2015). The highest $\mathrm{CO}_{2}$ emission was similarly measured at the aeration tank. The other major resource of $\mathrm{CO}_{2}$ emission was the primary settling tank. In this study, no greenhouse gases were released at primary settling tank. Kyung et al. (2015) reported the direct GHG emission in the value of $3701 \pm 269 \mathrm{~kg} \mathrm{CO}_{2}$-eq/d. They monitored higher emissions than this study. It could be said that 5-staged Bardenpho process emitted more GHG emissions than chemical treatment combined with activated sludge process (Kyung et al. 2015) Qiao et al. (2020) investigated on GHG emission from wastewater treatment process of combined activated sludge and microalgae processes. $\mathrm{No} \mathrm{CH}_{4}$ emissions were observed during the operation of the study. $\mathrm{CO}_{2}$ only released for small proportion of the total GHG (Qiao et al. 2020). Nayeb et al. (2019) reported wastewater collection, treatment and discharging systems led to direct greenhouse gas emission at activated sludge process and energy consumption led to indirect emissions, similarly (Nayeb et al. 2019).

\section{Indirect GHG emissions}

The indirect GHG emission was regarded as the emissions from electricity consumption for this study. There is no sludge stabilization and disposal process in this plant. Therefore, the indirect emission from sludge treatment was ignored, in this study. The amount of the indirect greenhouse gas emissions due to electricity consumption of the plant is given in Table 6. Figure 6 shows monthly variation of the indirect GHG emissions.

The variation of the indirect GHG emissions was directly related to the electricity consumption. The amount of GHG emissions increased as the electricity consumption increased. The highest indirect greenhouse gas emission was reported formed in May (1241.79 $\mathrm{kg} \mathrm{CO}_{2}$-eq/d) due to the highest electricity consumption $(74,957.680 \mathrm{kWh})$. The lowest indirect GHG emission was recorded in August (769.94 $\mathrm{kg} \mathrm{CO}_{2}$-eq/d) due to the lowest value in electricity consumption $(46,475.64 \mathrm{kWh})$.

Kyung et al. (2015) performed a similar study (Kyung et al. 2015). They estimated the indirect GHG emission from 


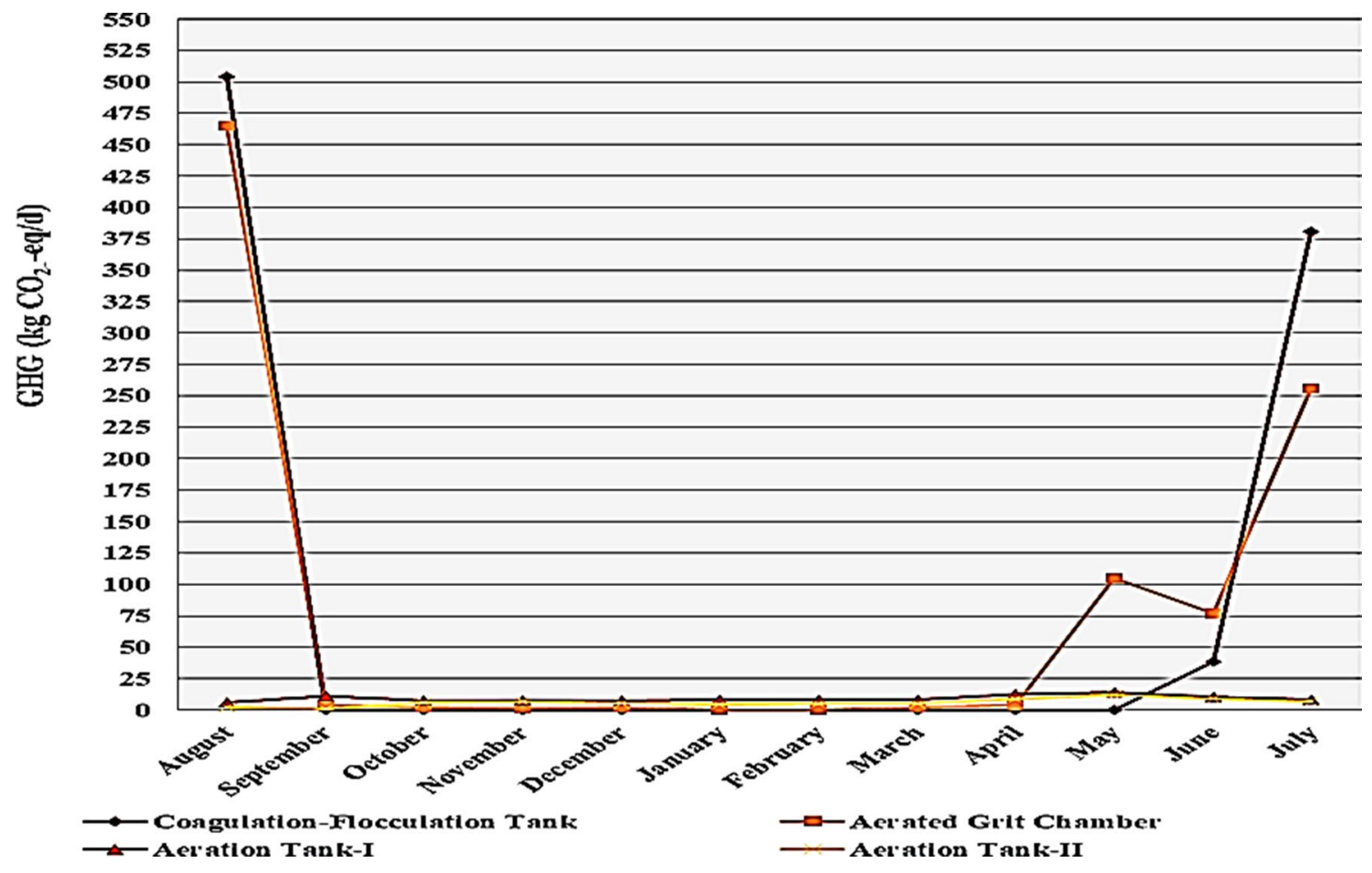

Fig. $4 \mathrm{GHG}_{\text {direct }}$ emission variation on process basis

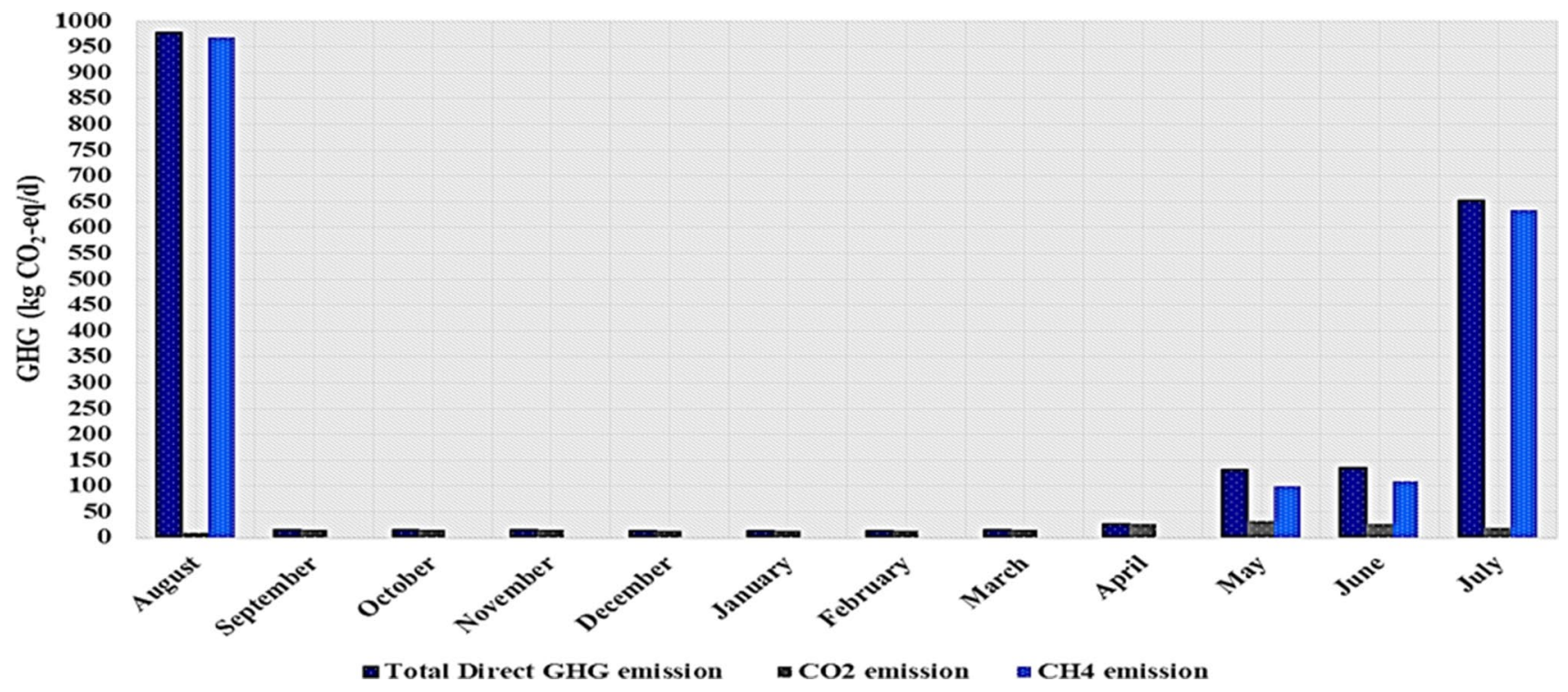

Fig5 Monthly change of $\mathrm{GHG}_{\text {direct }}$ emissions

electricity consumption and chemical use using a similar method. They reported similarly that the indirect greenhouse gas emission was found to be $1893 \pm 240 \mathrm{~kg} \mathrm{CO}_{2}$-eq/d. It was reported that the highest indirect emission was emitted from the aerobic unit. As the electricity consumption is observed using the counter connected to the main transformer, the indirect greenhouse gas emission assessment could not be made based on the process, and only the assessment was carried out monthly in this study. It could be estimated that the blowers used as the air supplier consumed the highest electricity in the aeration tanks in this study. Another study was related to Shahabadi et al. (2009). They achieved similar results with this study (Shahabadi et al. 2009). The indirect emission value of the aerobic system was $1313 \mathrm{~kg}$ 
Table $4 \mathrm{GHG}_{\text {indirect }}$ emission

\begin{tabular}{lllc}
\hline Months & $\mathrm{EC}(\mathrm{kWh})$ & $\begin{array}{l}\mathrm{Ef}\left(\mathrm{kg} \mathrm{CO} \mathrm{CO}_{2} \text {-eq/ }\right. \\
\mathrm{kWh})\end{array}$ & $\begin{array}{l}\mathrm{GHG}_{\text {indirect }}(\mathrm{kg} \\
\left.\mathrm{CO}_{2} \text {-eq } / \mathrm{d}\right)\end{array}$ \\
\hline August & $46,475.64$ & 0.497 & 769.94 \\
September & $52,301.655$ & 0.497 & 866.46 \\
October & $63,066.69$ & 0.497 & 1044.80 \\
November & $72,453.105$ & 0.497 & 1200.30 \\
December & $74,333.700$ & 0.497 & 1231.46 \\
January & $74,747.700$ & 0.497 & 1238.32 \\
February & $62,457.075$ & 0.497 & 1034.70 \\
March & $70,110.250$ & 0.497 & 1161.49 \\
April & $72,027.700$ & 0.497 & 1193.25 \\
May & $74,957.680$ & 0.497 & 1241.79 \\
June & 59,115 & 0.497 & 979.34 \\
July & 54,110 & 0.497 & 896.42 \\
\hline
\end{tabular}

Table $5 \mathrm{GHG}_{\text {total }}$ emission

\begin{tabular}{lccc}
\hline Months & $\begin{array}{l}\mathrm{GHG}_{\text {direct }}(\mathrm{kg} \\
\left.\mathrm{CO}_{2} \text {-eq/d }\right)\end{array}$ & $\begin{array}{l}\mathrm{GHG}_{\text {indirect }}(\mathrm{kg} \\
\mathrm{CO}_{2} \text {-eq/d) }\end{array}$ & $\begin{array}{l}\text { GHGto- } \\
\text { tal }(\mathrm{kg} \\
\mathrm{CO}_{2} \text {-eq/d) }\end{array}$ \\
\hline August & 977.76 & 769.94 & 1747.70 \\
September & 15.768 & 866.46 & 882.23 \\
October & 15.624 & 1044.80 & 1060.42 \\
November & 15.408 & 1200.30 & 1215.71 \\
December & 12.6 & 1231.46 & 1244.06 \\
January & 12.456 & 1238.32 & 1250.77 \\
February & 12.888 & 1034.70 & 1047.59 \\
March & 15.696 & 1161.49 & 1177.18 \\
April & 25.344 & 1193.25 & 1218.60 \\
May & 131.184 & 1241.79 & 1372.98 \\
June & 135.072 & 979.34 & 1114.41 \\
July & 651.456 & 896.42 & 1547.88 \\
\hline
\end{tabular}

Table 6 Benchmarking of monitoring results with the previous studies

\begin{tabular}{|c|c|c|}
\hline References & $\begin{array}{l}\text { GHGto- } \\
\text { tal (kg } \\
\mathrm{CO}_{2} \text {-eq/d) }\end{array}$ & Existing treatment process \\
\hline This study & 1747.70 & $\begin{array}{l}\text { Chemical Treatment }+ \text { Activated } \\
\text { Sludge Process }\end{array}$ \\
\hline $\begin{array}{l}\text { Shahabadi et al. } \\
\text { (2009) }\end{array}$ & 6617 & $\begin{array}{l}\text { Anaerobic Treatment }+\mathrm{AO} \\
\text { Process }\end{array}$ \\
\hline Kyung et al. (2015) & 12.855 & 5-staged Bardenpho Process \\
\hline Barbu et al. (2017) & 17.961 & Activated Sludge Process \\
\hline Santin et al. (2018) & 17.851 & Activated Sludge Process \\
\hline
\end{tabular}

$\mathrm{CO}_{2}$-eq/d. They also considered the use of chemicals at the calculation of the indirect emission and found that the highest amount of the indirect emissions was due to chemical use. Masuda et al. (2015) reported that the indirect emission arising from electricity consumption was $43.4 \%$ of the total emission(Masuda et al. 2015). Oppositely, it was reported that electricity consumption constituted higher ratio in total GHG emissions, in this study. In a study by Nayeb et al. (2019), they reported that indirect $\mathrm{CO}_{2}$ emission is associated with the energy consumption in WWTPs based on the population covered and energy efficiency (Nayeb et al. 2019).

\section{Total GHG emissions}

Total greenhouse gas emission is given in Table 7. Figure 7 demonstrated monthly variation of total greenhouse gas emissions.

It was observed that total greenhouse gas emission was closely related to the variation of indirect GHG emission. Except for August (direct emission was higher than indirect emission), the indirect greenhouse gas emissions constituted the biggest share of total GHG emissions. Direct greenhouse gas emissions from the process were relatively lower than indirect greenhouse gas emissions. As seen from Fig. 5, the trend in indirect greenhouse gas emissions was similar and coincides with total greenhouse gas emissions. Based on this consideration, it could be concluded that direct greenhouse gas emissions are the key indicator in the formation of total greenhouse gas emissions. The indirect greenhouse gas emissions constituted a large part of total greenhouse gas emissions. The highest total greenhouse gas emission value was observed in August (1747.70 $\mathrm{kg} \mathrm{CO}_{2}$-eq/d). It could be originated from the highest direct $\mathrm{CH}_{4}$ emission was observed in August. From this point of view, it could be said that $\mathrm{CH}_{4}$ was determiner $\mathrm{GHG}$ for total $\mathrm{GHG}$ emissions. The lowest total greenhouse gas emission was observed in September $\left(882.23 \mathrm{~kg} \mathrm{CO}_{2}\right.$-eq/d). When the process conditions were evaluated, it was observed the highest total greenhouse gas emission at the lowest flow rate and COD concentrations (August). It was due to the direct $\mathrm{CH}_{4}$ emission generation.

Kyung et al. (2015) found the total greenhouse gas emission as $12.855 \mathrm{~kg} \mathrm{CO}_{2}$-eq/d. The high value was due to $\mathrm{CH}_{4}$ emission in the aeration tank. In this study, since $\mathrm{CH}_{4}$ emission was only monitored in August, May, June and Jul, the total greenhouse gas emission was lower compared to their study (1747.70 $\mathrm{kg} \mathrm{CO}_{2}$-eq/d)(Kyung et al. 2015). It showed that industrial wastewater treatment systems emitted less greenhouse gas emissions than municipal ones. Shahabadi et al. (2009) achieved similar results with this study. In their study, they found that highest amount of the total greenhouse gas emissions was caused by indirect emissions for the hybrid system (Shahabadi et al. 2009). The value 


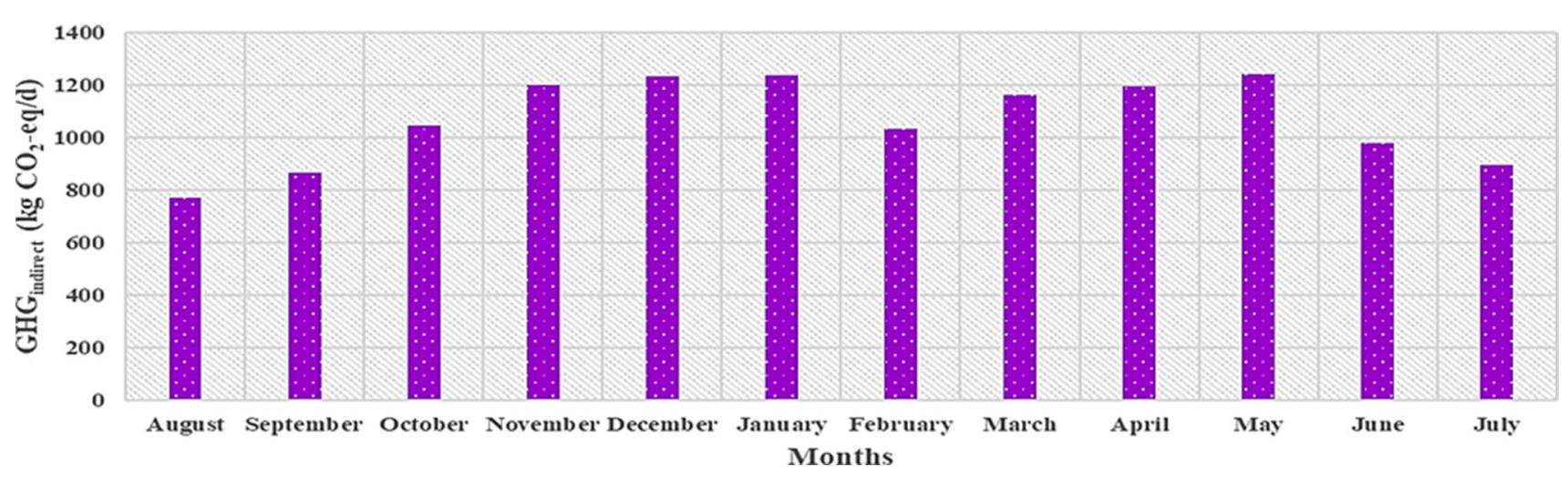

Fig. 6 Monthly change of $\mathrm{GHG}_{\text {indirect }}$ emissions

Table 7 GHG emission minimization results using Monte Carlo simulation

\begin{tabular}{|c|c|c|c|c|c|c|c|}
\hline Months & $\begin{array}{l}\text { Opera- } \\
\text { tional } \\
\text { COD } \\
(\mathrm{mg} / \mathrm{L})\end{array}$ & $\begin{array}{l}\text { Operational } \\
\text { flow rate } \\
\left(\mathrm{m}^{3} / \mathrm{d}\right)\end{array}$ & $\begin{array}{l}\mathrm{GHG}_{\text {direct }} \text { emission } \\
\left(\mathrm{kg} \mathrm{CO}_{2} \text {-eq/d) }\right.\end{array}$ & $\begin{array}{l}\text { Possible minimum GHG } \\
\text { emission }\left(\mathrm{kg} \mathrm{CO}_{2} \text {-eq/d) }\right.\end{array}$ & $\begin{array}{l}\text { Design } \\
\text { COD }(\mathrm{mg} / \mathrm{L})\end{array}$ & $\begin{array}{l}\text { Design } \\
\text { flow rate }\left(\mathrm{m}^{3} / \mathrm{d}\right)\end{array}$ & Reduction (\%) \\
\hline August & 997 & 1190 & 977.76 & 722.5 & 10,000 & 6000 & 26.11 \\
\hline September & 2319 & 2245 & 15.768 & 11.025 & 10,000 & 6000 & 30.08 \\
\hline October & 5714 & 3540 & 15.624 & 11.50 & 10,000 & 6000 & 26.40 \\
\hline November & 5537 & 3525 & 15.408 & 10.00 & 10,000 & 6000 & 35.10 \\
\hline December & 5639 & 3530 & 12.6 & 9.50 & 10,000 & 6000 & 24.60 \\
\hline January & 3399 & 3535 & 12.456 & 8.25 & 10,000 & 6000 & 33.77 \\
\hline February & 8088 & 3510 & 12.888 & 10.55 & 10,000 & 6000 & 18.14 \\
\hline March & 4896 & 3540 & 15.696 & 11.33 & 10,000 & 6000 & 27.82 \\
\hline April & 4225 & 3530 & 25.344 & 18.22 & 10,000 & 6000 & 28.11 \\
\hline May & 4027 & 3545 & 131.184 & 95.25 & 10,000 & 6000 & 27.39 \\
\hline June & 1997 & 1790 & 135.072 & 108.75 & 10,000 & 6000 & 19.49 \\
\hline July & 1027 & 1230 & 651.456 & 400.15 & 10,000 & 6000 & 38.58 \\
\hline
\end{tabular}

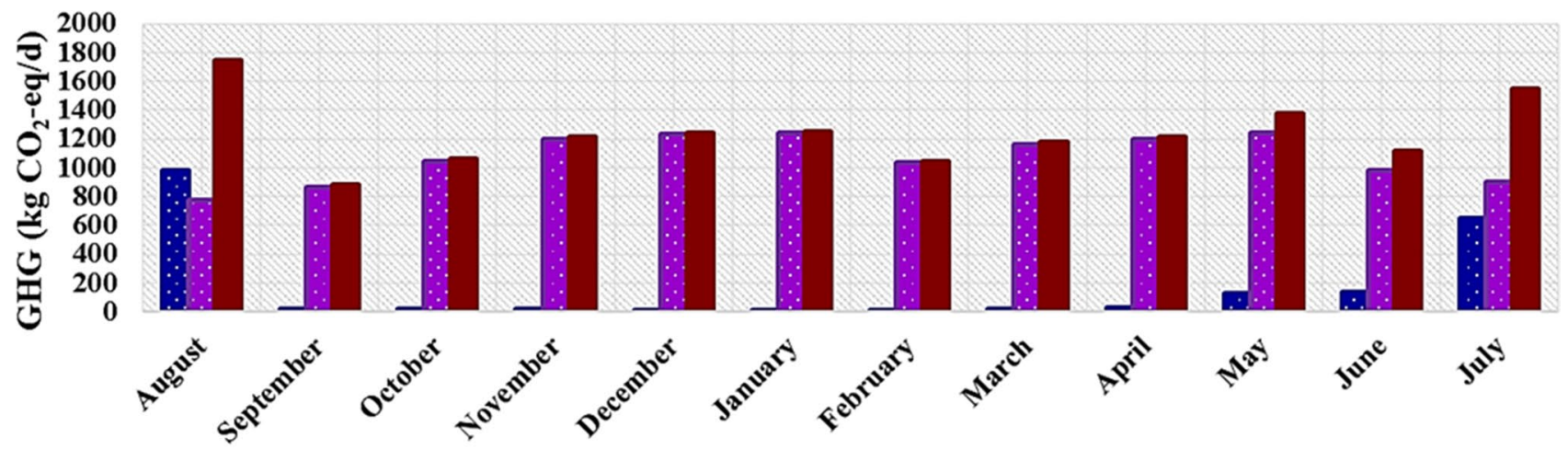

\section{GHGdirect Emission (kg CO2-eq/d) GHGindirect Emission (kg CO2-eq/d)}

GHGtotal Emission (kg CO2-eq/d)

Fig. 7 Monthly variation of $\mathrm{GHG}_{\text {total }}$ emissions 
of $\mathrm{GHG}$ emission was $6617 \mathrm{~kg} \mathrm{CO}_{2}$-eq/d. It indicated that they detected higher amounts of greenhouse gas emissions from hybrid systems than this plant. Comparative evaluation with the literature is given in Table 6. Barbu et al. (2017) estimated the GHG emission from activated sludge process in the value of $17.961 \mathrm{~kg} \mathrm{CO}_{2}$-eq/d (Barbu et al. 2017). In the study of Santin et al. (2018), the GHG emission from classical activated sludge process was $17.851 \mathrm{~kg} \mathrm{CO}_{2}$-eq/d. It could be considered that only aeration process emits higher GHG emissions than combined activated sludge and chemical treatment process (Santín et al. 2018). It could be originated from $\mathrm{CH}_{4}$ emissions. For some activated sludge systems, air consumption is lower, so some un-aerated zones could be formed, and these conditions lead to $\mathrm{CH}_{4}$ emissions.

In addition, taking under control of energy consumption is one of the most effective strategies in order to decrease the indirect $\mathrm{CO}_{2}$ emissions. The GHG emissions minimization can be achieved if energy efficiency applications are used in the plant. Also, $\mathrm{CH}_{4}$ emissions led to the highest GHG emission in this plant. $\mathrm{CH}_{4}$ emissions should be prevented for coagulation-flocculation tank and aerated grit chamber. $\mathrm{CH}_{4}$ emissions could be originated from anaerobic conditions. These conditions could be limited with the adequate aeration. Also, planned maintenance activities (pump, blower, treatment units, nozzle, pipes, etc.) should be improved for the treatment units.

\section{GHG emissions minimization after Monte Carlo simulation}

For the possible minimization of GHG emissions, the effects of design and operational conditions on GHG emissions were examined in water-energy nexus. Only direct emissions were considered for the simulation study. Since, the process conditions were relatively closed with the direct emissions. Table 7 demonstrates the simulation and minimization results.

According to the simulation results, it is possible to minimize the GHG emission if the plant is operated under design conditions. The minimum greenhouse gas emission would be $8.25 \mathrm{~kg} \mathrm{CO}_{2}$-eq/d if the plant was operated at $10,000 \mathrm{mg} / \mathrm{L}$ of COD and $6000 \mathrm{~m}^{3} / \mathrm{d}$ of flow rate in January. If the plant is operated under the design conditions, it could be a reduction of nearly $30 \%$ in greenhouse gas emissions.

A similar study was performed by Kyung et al. (2015). They used Crystal Ball, Ver. 11.1. Oracle software. The uncertainty analysis was applied, and the possible variation of greenhouse gas emissions was determined using Monte Carlo Simulation (Kyung et al. 2015). This study aims to determine the minimized GHG emission value using the correlation between the operational parameters and GHG emission. Also, Kim et al. (2015) studied on the optimization of a WWTP considering GHG emissions. ASMN_G model was used to optimize the process conditions in the plant (Kim et al. 2015). The originality of this study that the effect of design conditions in terms of COD and wastewater flow on GHG emissions was investigated and the possible GHG emission reduction was estimated using Monte Carlo simulation. Sweetapple et al. (2014) investigated the optimization potential for the minimization of operational GHG emissions from wastewater treatment which activated sludge process was carried out (Sweetapple et al. 2014). They reported that multi-objective optimization of WWTP operational parameters and an important minimization in GHG emissions. They estimated and optimized GHG emissions using BSM2G model in terms of COD and BOD removal. Flores-Alsina et al. (2011) investigated the GHG emissions benchmarking of wastewater treatment process control strategies and modeling of activated sludge process (Flores-Alsina et al. 2011). They used BSM2G method considering the dissolved oxygen, the solid retention time (SRT) and the organic carbon/ nitrogen ratio $(\mathrm{COD} / \mathrm{N})$ as promoters of $\mathrm{GHG}$ emissions.

\section{Conclusion}

This study confirms that industrial wastewater treatment plants are one of the GHG emissions resources. Coagulation-flocculation tank was the main treatment unit which emitted the GHG emissions in the plant. It could be considered that $\mathrm{CH}_{4}$ emission was emitted in the summer due to anaerobic stratification in the coagulation-flocculation tank. At aerated grit chamber, it could be correlated that $\mathrm{CH}_{4}$ was released due to anaerobic conditions in compartments that were not adequately aerated. Aeration tanks were the main resources of $\mathrm{CO}_{2}$ emissions. Here, it could be said that $\mathrm{CO}_{2}$ emission was released due to the respiration of the living microbial mass. The results showed that the highest direct greenhouse gas emissions occurred in August $(977.76 \mathrm{~kg}$ $\mathrm{CO}_{2}$-eq/d). The lowest direct greenhouse gas emission was monitored in January (12.456 $\mathrm{kg} \mathrm{CO}_{2}$-eq/d). The indirect emissions were higher than the direct emissions in the plant except for August. The indirect emission from electricity consumption constituted the highest amount in total emissions.

Monte Carlo simulation results revealed that minimization of greenhouse gas emissions may be possible if wastewater plant is operated under design conditions in terms of water-energy nexus. The minimum greenhouse gas emission in the result of the simulation study is $8.25 \mathrm{~kg} \mathrm{CO}_{2}$-eq/d if the plant is operated under design COD and flow rate. Total reduction in GHG emissions is approximately $30 \%$ if the plant is operated under design conditions in terms of water-energy nexus. It should be originated that if the plant is operated in full-capacity, the energy loss leakage could be 
lower and even so the not only electricity consumption but also GHG emissions would be reduced.

Acknowledgements The authors are thankful to HUBAK (Harran University Scientific Research Council) for their financial support. (Project Number: 16216). Also, the authors are grateful to Industrial Wastewater Treatment Plant Employees and Authorities for their support.

Author contributions (if applicable) Pelin Yapıcıŏlu (PY) and Özlem Demir (ÖD).

Funding Yes. HUBAK (Harran University Scientific Research Council) with the project.

\section{Declarations}

Conflict of interest Yapıcıoğlu, P. and Demir, O. state that there are no conflict of interest.

Human and animal rights This article does not contain any studies with human or animal subjects.

Open Access This article is licensed under a Creative Commons Attribution 4.0 International License, which permits use, sharing, adaptation, distribution and reproduction in any medium or format, as long as you give appropriate credit to the original author(s) and the source, provide a link to the Creative Commons licence, and indicate if changes were made. The images or other third party material in this article are included in the article's Creative Commons licence, unless indicated otherwise in a credit line to the material. If material is not included in the article's Creative Commons licence and your intended use is not permitted by statutory regulation or exceeds the permitted use, you will need to obtain permission directly from the copyright holder. To view a copy of this licence, visit http://creativecommons.org/licenses/by/4.0/.

\section{References}

APHA (2005) Standard methods for the examination of water and wastewater.

Barbu M, Vilanova R, Meneses M, Santin I (2017) On the evaluation of the global impact of control strategies applied to wastewater treatment plants. J Clean Prod 149:396-405. https://doi.org/10. 1016/j.jclepro.2017.02.018

Castellet-Viciano L, Torregrossa D, Hernández-Sancho F (2018) The relevance of the design characteristics to the optimal operation of wastewater treatment plants: energy cost assessment. J Environ Manage 222:275-283. https://doi.org/10.1016/j.jenvman.2018. 05.049

Flores-Alsina X, Corominas L, Snip L, Vanrolleghem PA (2011) Including greenhouse gas emissions during benchmarking of wastewater treatment plant control strategies. Water Res 45:47004710. https://doi.org/10.1016/j.watres.2011.04.040

Guo L, Vanrolleghem PA (2014) Calibration and validation of an activated sludge model for greenhouse gases no. 1 (ASMG1): prediction of temperature-dependent $\mathrm{N} 2 \mathrm{O}$ emission dynamics. Bioprocess Biosyst Eng 37:151-163. https://doi.org/10.1007/ s00449-013-0978-3

International Energy Agency (IEA) (2016) Key world energy statistics 2016 (also available on. Int Energy Agency Secur Sustain Together. https://doi.org/10.1787/9789264039537-en
IPCC 2014 (2014) Climate change 2014: mitigation of climate change. summary for policymakers and technical summary

Kim D, Bowen JD, Ozelkan EC (2015) Optimization of wastewater treatment plant operation for greenhouse gas mitigation. J Environ Manage 163:39-48. https://doi.org/10.1016/j.jenvman.2015. 07.005

Kroese DP, Brereton T, Taimre T, Botev ZI (2014) Why the Monte Carlo method is so important today. Wiley Interdiscip Rev Comput Stat 6:386-392. https://doi.org/10.1002/wics.1314

Kumar A, Thanki A, Padhiyar H, Singh NK, Pandey S, Yadav M, Yu ZG (2021) Greenhouse gases emission control in WWTS via potential operational strategies: a critical review. Chemosphere. https://doi.org/10.1016/j.chemosphere.2021.129694

Kumar A, Yang T, Sharma MP (2019a) Greenhouse gas measurement from Chinese freshwater bodies: a review. J Clean Prod 233:368378. https://doi.org/10.1016/j.jclepro.2019.06.052

Kumar A, Yang T, Sharma MP (2019b) Long-term prediction of greenhouse gas risk to the Chinese hydropower reservoirs. Sci Total Environ 646:300-308. https://doi.org/10.1016/j.scitotenv.2018. 07.314

Kyung D, Kim M, Chang J, Lee W (2015) Estimation of greenhouse gas emissions from a hybrid wastewater treatment plant. J Clean Prod 95:117-123. https://doi.org/10.1016/j.jclepro.2015.02.032

Landa-Cansigno O, Behzadian K, Davila-Cano DI, Campos L (2020) Performance assessment of water reuse trategies using integrated framework of urban water metabolism and water-energy-pollution nexus. Environ Sci Pollut Res 27:4582-4597. https://doi.org/10. 1007/s11356-019-05465-8

Maity JP, Bundschuh J, Chen CY, Bhattacharya P (2014) Microalgae for third generation biofuel production, mitigation ofgreenhouse gas emissions and wastewater treatment: present andfuture perspectives-a mini review. Energy 78:104-113. https://doi.org/10. 1016/j.energy.2014.04.003

Mannina G, Ekama G, Caniani D et al (2016) Greenhouse gases from wastewater treatment-a review of modelling tools. Sci Total Environ 551-552:254-270. https://doi.org/10.1016/j.scitotenv.2016. 01.163

Masuda S, Suzuki S, Sano I et al (2015) The seasonal variation of emission of greenhouse gases from a full-scale sewage treatment plant. Chemosphere 140:167-173. https://doi.org/10.1016/j. chemosphere.2014.09.042

Metcalf \& Eddy (2014) Wastewater engineering: treatment and resource recovery 5 th. McGraw-Hill international Editions.

Molinos-Senante M, Hernández-Sancho F, Mocholí-Arce M, SalaGarrido R (2014) Economic and environmental performance of wastewater treatment plants: potential reductions in greenhouse gases emissions. Resour Energy Econ 38:125-140. https://doi.org/ 10.1016/j.reseneeco.2014.07.001

Nayeb H, Mirabi M, Motiee H et al (2019) Estimating greenhouse gas emissions from Iran's domestic wastewater sector and modeling the emission scenarios by 2030. J Clean Prod 236:117673. https:// doi.org/10.1016/j.jclepro.2019.117673

Parravicini V, Svardal K, Krampe J (2016) Greenhouse gas emissions from wastewater treatment plants. Energy Procedia 97:246-253. https://doi.org/10.1016/j.egypro.2016.10.067

Pata UK, Kumar A (2021) The Influence of hydropower and coal consumption on greenhouse gas emissions: a comparison between China and India. Water 13(10):1387. https://doi.org/10.3390/ w13101387

Qambrani NA, Rahman MM, Won S et al (2017) Biochar properties and eco-friendly applications for climate change mitigation, waste management, and wastewater treatment: a review. Renew Sustain Energy Rev 79:255-273. https://doi.org/10.1016/j.rser.2017.05. 057

Qiao S, Hou C, Wang X, Zhou J (2020) Minimizing greenhouse gas emission from wastewater treatment process by integrating

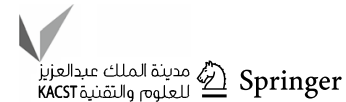


activated sludge and microalgae processes. Sci Total Environ 732:139032. https://doi.org/10.1016/j.scitotenv.2020.139032

Rodriguez-Caballero A, Aymerich I, Poch M, Pijuan M (2014) Science of the total environment evaluation of process conditions triggering emissions of green-house gases from a biological wastewater treatment system. Sci Total Environ 493:384-391. https://doi.org/ 10.1016/j.scitotenv.2014.06.015

Santin I, Barbu M, Pedret C, Vilanova R (2018) Fuzzy logic for plantwide control of biological wastewater treatment process including greenhouse gas emissions. ISA Trans 77:146-166. https://doi.org/ 10.1016/j.isatra.2018.04.006

Shahabadi MB, Yerushalmi L, Haghighat F (2009) Impact of process design on greenhouse gas (GHG) generation by wastewater treatment plants. Water Res 43(10):2679-2687. https://doi.org/10. 1016/j.watres.2009.02.040

Sweetapple C, Fu G, Butler D (2014) Multi-objective optimisation of wastewater treatment plant control to reduce greenhouse gas emissions. Water Res 55:52-62. https://doi.org/10.1016/j.watres. 2014.02.018

Yapıcıŏlu P, Demir Ö (2017) An overview of climate change and greenhouse effects for wastewater treatment plants. Uludağ Univ J Fac Eng 22:235-250

Yapıcıoğlu P, Yeşilnacar MI (2020) Energy cost assessment of a dairy industry wastewater treatment plant. Environ Monit Assess 192(8):1-17. https://doi.org/10.1007/s10661-020-08492-y

Publisher's Note Springer Nature remains neutral with regard to jurisdictional claims in published maps and institutional affiliations. 